\title{
Gender, Komisaris Independen, Ukuran Dewan, Komite Audit, dan Pengungkapan Tanggung Jawab Sosial Perusahaan
}

\author{
Novita Anggraeni \\ Fakultas Ekonomi dan Bisnis \\ Universitas Airlangga, Indonesia \\ Email: novitaanggraeni515@gmail.com
}

\begin{abstract}
ABSTRAK
Penelitian ini tujuannya adalah menguji pengaruh gender, dewan komisaris independen, ukuran dewan dan komite audit terhadap pengungkapan tanggungjawab sosial perusahaan (Corporate Sosial Resonsibility). Sampelnya menggunakan perusahaan yang tercatat di database Global Reporting Index dan tercatat di Bursa Efek Indonesia selama 2013-2018, yang jumlahnya 340 perusahaan-tahun. Data diperoleh dari laporan tahunan dan laporan keberlanjutan (sustainability report). Pendekatan yang digunakan yaitu kuantitatif dan teknik analisis data yang digunakan adalah analisa regresi linear berganda. Hasil penelitiannya memperlihatkan jika ukuran dewan dan komite audit mempengaruhi secara positif terhadap pengungkapan tanggung jawab sosial perusahaan. Komisaris independen mempengaruhi secara negatif terhadap pengungkapan tanggung jawab sosial perusahaan, dan tidak ditemukan bukti pengaruh gender terhadap pengungkapan tanggung jawab sosial perusahaan.
\end{abstract}

Kata Kunci: Pengungkapan Tanggung JawabSosial Perusahaan; Gender; Dewan Komisaris Independen; Ukuran Dewan; Komite Audit.

Gender, Independent Commissioner, Board Size, Audit Committee, and Corporate Social Responsibility Disclosure

\begin{abstract}
This research aims to determine the effect of gender, independent commissioners, board size and audit committee on corporate social responsibility disclosure index. Sample used are companies listed on the Global Reporting Index database and listed on the Indonesia Stock Exchange for period 2013-2018, as many as 340 company-years. The sources of the data were taken from annual reports and sustainability reports. This research uses a quantitative approach and data analysis technique used is multiple linear regression analysis. The results shows that the size of the board and audit committee have a positive effect on corporate social responsibility disclosures. Independent commissioners have a negatif effect on corporate social responsibility disclosure, and no evidence of the effect of gender on corporate social responsibility disclosure.
\end{abstract}

Keywords: Corporate Social Responsibility Disclosure; Gender; Independent Commissioners; Board Size; Audit Committee.

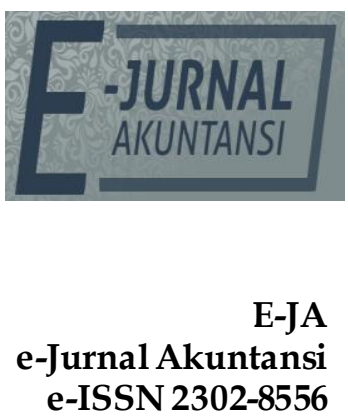

Vol. 30 No. 7

Denpasar, Juli 2020

Hal.1827-1842

Artikel Masuk:

5 Maret 2020

Tanggal Diterima:

9 Juli 2020

The Article is Available in: https://ojs.unud.ac.id/index.php/Akuntansi/index 


\section{PENDAHULUAN}

Masalah tanggung jawab sosial pada negara-negara berkembang telah mendapat perhatian yang meningkat dari praktisi dan akademisi. Tanggung jawab sosial perusahaan yang berorientasi pada konsumen bisa menaikkan prestise perusahaan, selanjutnya dapat menciptakan diferensiasi produk dan menghasilkan lebih banyak keuntungan (Kabir \& Thai, 2017). Pengungkapan tanggung jawab sosial perusahaan penting untuk meningkatkan kesejahteraan sosial yang berfungsi sebagai sarana untuk meningkatkan hubungan dengan para pemangku kepentingan (Garcia-Sanchez et al., 2014), legitimasi perusahaan (Martínez-Ferrero et al., 2015), kepercayaan dan reputasi (El Ghoul et al., 2011), dan kinerja perusahaan (Michelon et al.,2015).

Dalam praktiknya, pengungkapan tanggung jawab sosial perusahaan masih menunjukkan informasi yang rendah, khususnya pada negara-negara berkembang (Katmon et al., 2017). Berdasarkan penelitian Centre for Governance, Institutions, and Organizations dari National University of Singapore (NUS) yang dilakukan oleh Loh et al., (2016) dengan menilai tingkat pengungkapan berdasarkan indikator GRI menunjukkan jika pengungkapan tanggung jawab sosial perusahaan di Indonesia rendah apabila dibandingkan dengan perusahaan di Thailand dan Singapura, pengungkapan tanggung jawab sosial di Indonesia memiliki nilai 48,4, Malaysia 47,7, sedangkan Thailand 56,8 dan Singapura 48,8.

Global Reporting Initiative (GRI) memperkenalkan sebuah pedoman berisi standard pengungkapan, sehingga memudahkan perusahaan dalam menyusun laporan keberlanjutan. Kepatuhan terhadap standard pelaporan seperti Global Reporting Initiative (GRI) akan membantu meningkatkan kredibilitas laporan tanggung jawab sosial perusahaan (Fernández-Gago et al., 2016). Kebaruan dalam penelitian ini adalah dengan menggunakan tiga jenis indeks GRI yakni G3.1, G4 dan GRI Standard dalam mengukur pengungkapan tanggung jawab sosial perusahaan, hal ini dikarenakan GRI memperbarui indikator secara rutin karena persepsi dan kebutuhan publik atas tanggung jawab sosial perusahaan selalu berubah, dan dalam penelitian ini juga menggunakan perusahaanperusahaan yang terdaftar di database GRI karena perusahaan-perusahaan tersebut dianggap memiliki kepedulian terhadap keberlanjutan perusahaan.

Di Indonesia terdapat beberapa peraturan yang mewajibkan pengungkapan tangggung jawab sosial perusahaan yakni Undang Undang No. 40 tahun 2007 mengenai Perseroan Terbatas, Peraturan Pemerintah No. 47 tahun 2012 mengenai tanggung jawab sosial dan lingkungan, dan juga Bapepam No. X.K.6 tahun 2006 mengenai cara menyampaikan laporan tahunan emiten atau perusahaan publik yang mengharuskan semua perusahaan terbuka untuk mengungkapkan aktivitas dan biaya yang berkaitan dengan tanggung jawab sosial perusahaan dalam laporan keuangannya. Undang Undang dan peraturan yang dikeluarkan oleh pemerintah ini mengharuskan bahwa operasi perusahaan selain selaras dengan tujuan perusahaan juga harus selaras dengan pemangku kepentingan (stakeholder). Elkington (1997) mengemukakan gagasan "triple bottom line - profit, people, planet", gagasan tersebut memperlihatkan jika perusahaan tidak hanya memiliki tanggung jawab terhadap keuangannya saja, akan tetapi juga memiliki tanggung jawab dalam aspek lingkungan dan sosial. Hal tersebut 
menggambarkan jika keadaan keuangan saja tidak cukup dalam memberikan jaminan terhadap keberlanjutan perusahaan.

Pengungkapan tanggung jawab sosial perusahaan dilaksanakan oleh direksi berpegang pada persetujuan dewan komisaris sesuai yang tertuang didalam Peraturan Pemerintah nomor 47 tahun 2012. Oleh karena itu, direksi dan dewan komisaris mempunyai peranan yang relevan dalam peningkatan transparansi perusahaan dengan meningkatkan pelaporan tanggung jawab sosial perusahaan. Keberlangsungan perusahaan dan keberhasilan yang berkelanjutan bergantung pada kemampuan manajernya dalam menciptakan kekayaan, nilai, atau kepuasan yang cukup bagi setiap pemangku kepentingan (Clarkson, 1995).

Mengingat relevansi tanggung jawab sosial perusahaan, perlu untuk memeriksa mekanisme tata kelola perusahaan khususnya komposisi dewan dan pengaruhnya terhadap pengungkapan tanggung jawab sosial perusahaan (Rao and Tilt, 2016). Penelitian ini berfokus pada gender direksi dan dewan komisaris, komisaris independen, ukuran dewan, dan komite audit. Gender adalah konsep yang memandang bahwa terdapat perbedaan antara laki-laki dan perempuan dalam pengambilan keputusan. Perempuan memiliki sifat psikologis tertentu yang membuat mereka lebih bersedia untuk fokus dan menghargai klaim pemangku kepentingan tertentu (Liao et al., 2015), perempuan lebih berbelas kasih, simpati, sopan, kepekaan antar pribadi dan kepedulian terhadap kesejahteraan orang lain (Cabeza Garcia et al., 2018), perempuan memainkan peran penting sebagai pendukung pengungkapan tanggung jawab sosial perusahaan tidak hanya di tingkat direktur sebuah perusahaan tetapi juga sebagai pemangku kepentingan penting dari bisnis (Azam et al., 2019). Penelitian sebelumnya menunjukkan dewan dengan jumlah direktur perempuan yang lebih besar lebih cenderung terlibat dalam kegiatan tanggung jawab sosial perusahaan (Rao \& Tilt, 2016) dan (Ibrahim \& Hanefah, 2016). Sebaliknya, Muttakin et al., (2015) dan Zhuang et al., (2018) menunjukkan bahwa semakin tinggi proporsi perempuan dalam dewan menghasilkan tingkat pengungkapan tanggung jawab sosial yang lebih rendah, hal ini dikarenakan direktur perempuan diangkat berdasarkan ikatan keluarga, cenderung melindungi kepentingan keluarga dan tidak terlalu peduli dengan pengungkapan tanggung jawab sosial perusahaan.

Dalam Undang-Undang perseroan terbatas dijelaskan bahwa komisaris independen yang ada di dalam pedoman tata kelola perusahaan yang baik adalah komisaris dari pihak luar. Yuliani (2019) menunjukkan bahwa komisaris independen berpengaruh positif terhadap pengungkapan tanggung jawab sosial perusahaan, hal ini mengindikasikan pengawasan dewan komisaris berjalan efektif ketika struktur personal independen dalam dewan komisaris semakin besar. Sebaliknya, Siregar et al., (2017) dan Noviani et al., (2017) menunjukkan bahwa komisaris independen tidak berpengaruh terhadap pengungkapan tanggung jawab sosial perusahaan. Ukuran dewan dan komite audit juga merupakan faktor yang mempengaruhi pengungkapan tanggung jawab sosial perusahaan. Samaha et al., (2012) menyatakan bahwa semakin besar jumlah anggota dewan, semakin kecil kemungkinan mereka dikendalikan oleh CEO, sehingga meningkatkan efektifitas proses pemantauan. Penelitian sebelumnya menunjukkan bahwa ukuran dewan berpengaruh positif pada pengungkapan 
tanggung jawab sosial perusahaan (Abu Qa'dan \& Suwaidan 2019). Sebaliknya, Rao \& Tilt (2016) dan El-Bassiouny (2019) menunjukkan ukuran dewan tidak berpengaruh terhadap pengungkapan tanggung jawab sosial perusahaan. Penelitian sebelumnya juga mendukung peran komite audit dalam mempromosikan standar corporate governance dan kegiatan sosial. Komite audit dapat mendukung dan membantu manajemen perusahaan dalam memberikan informasi yang lebih berkualitas (Khan et al., 2019). Fallah (2019) dan Katmon et al., (2017) menunjukkan bahwa ukuran komite audit berpengaruh positif terhadap pengungkapan tanggung jawab sosial perusahaan. Sebaliknya, Habbash (2016) menunjukkan tidak adanya pengaruh komite audit pada pengungkapan tanggung jawab sosial perusahaan. Tujuan penelitian ini adalah untuk menguji pengaruh gender, dewan komisaris independen, ukuran dewan, dan komite audit terhadap pengungkapan tanggung jawab sosial perusahaan.

Teori yang mendasari penelitian ini adalah teori stakeholder dan teori keagenan. Teori stakeholder menyatakan bahwa apa pun tujuan akhir kegiatan bisnis, manajer harus memperhitungkan kepentingan berbagai kelompok yang dapat mempengaruhi atau dipengaruhi oleh kegiatan mereka, pemangku kepentingan disini adalah orang-orang atau kelompok yang dapat mempengaruhi pencapaian tujuan perusahaan, atau yang dipengaruhi oleh pencapaian tujuan perusahaan (Freeman, 1984). Teori stakeholder menunjukkan bahwa direksi menjadi mekanisme kontrol utama dalam perusahaan dan bertanggung jawab kepada kelompok pemangku kepentingan yang lebih luas (Rao \& Tilt, 2016). Teori stakeholder telah digunakan untuk menjelaskan kegiatan pelaporan dalam banyak penelitian, menunjukkan bahwa pelaporan merupakan mekanisme akuntabilitas dan manajemen pemangku kepentingan.

Teori keagenan mendalilkan bahwa perbedaan kepentingan antara manajer dan pemilik dapat menimbulkan asimetri informatif antara para pihak karena pemilik cenderung mendelegasikan tanggung jawab mereka kepada manajer untuk membuat keputusan strategis atas nama mereka, menyebabkan masalah agensi (Fama \& Jensen, 1983). Teori keagenan menawarkan niat dewan direksi untuk memantau tindakan manajerial yang mempengaruhi pemegang saham, peran pemantauan ini memastikan bahwa kepentingan manajer sejalan dengan kepentingan pemegang saham, termasuk pemegang saham minoritas (Fama \& Jensen, 1983).

Secara sistematis kerangka konseptual penelitian dapat dilihat pada Gambar 1 berikut:

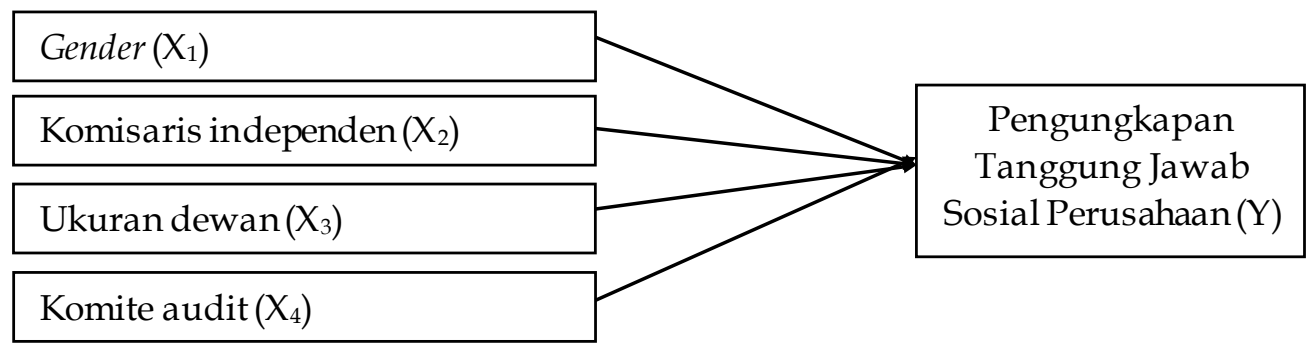

Sumber: Data Penelitian, 2020

Gambar 1. Kerangka Konseptual 
Teori stakeholder menyoroti saling ketergantungan antara perusahaan dan pemangku kepentingannya. Perempuan dalam jajaran direksi dan komisaris mampu mendorong perusahaan dalam membangun hubungan baik dengan para stakeholder, karena tingkat kepedulian perempuan yang tinggi terkait isu sosial dan lingkungan. Proporsi perempuan dalam dewan juga telah dikaitkan dengan konsep massa kritis dengan memiliki setidaknya tiga anggota dewan perempuan. Ketika jumlah perempuan lebih rendah, maka tidak membawa manfaat bagi perusahaan karena kekuatan mereka yang terbatas (Ahmad, 2018). Konsep massa kritis juga digunakan dalam analisis untuk menguji aspek spesifik dari pertanyaan penelitian mengenai konsekuensi yang diharapkan pada pengungkapan tanggung jawab sosial perusahaan, memiliki direktur perempuan mungkin tidak hanya bergantung pada persentase yang representatif mereka tetapi juga pada mencapai jumlah ambang batas yang sesuai (Cabeza Garcia et al., 2018).

Kehadiran perempuan dalam dewan dapat memperluas diskusi tentang isu-isu pemangku kepentingan, karena bertentangan dengan direktur laki-laki yang lebih berorientasi pada kinerja keuangan, direktur perempuan menunjukkan orientasi yang lebih kuat terhadap tanggung jawab sosial perusahaan (Biswas et al., 2018). Secara umum, perempuan dan laki-laki tampak berbeda nilainya dalam hal tanggung jawab sosial. Berbagai penelitian sudah dilaksanakan guna mengidentifikasi pengaruh gender dewan terhadap kewajiban sosial perusahaan, memiliki lebih banyak direktur perempuan berhubungan positif dengan pengungkapan tanggung jawab sosial perusahaan (Abu Qa' dan et al., 2019), (Biswas et al., 2018), dan (Naseem et al., 2017). Sesuai dengan kajian empiris hipotesis dirumuskan sebagai berikut:

$\mathrm{H}_{1}$ : Gender berpengaruh positif terhadap pengungkapan tanggung jawab sosial perusahaan.

Teori keagenan menjelaskan jika asimetri informasi secara inheren berada dalam organisasi karena manajer mempunyai banyak sekali informasi daripada pemegang sahamnya, hal tersebut bisa dikurangi oleh dewan aktif yang menjaga terhadap penyembunyian dan distorsi manajerial. Dua mekanisme yang mungkin dapat mengurangi masalah agensi dan informasi asimetris dan mengurangi biaya agensi adalah pengawasan dewan dan transparansi melalui pengungkapan. Dewan komisaris independen diperlukan dalam memberikan pengawasan pada manajemen semakin ketat dan memperkenalkam pengungkapan informasi. Jika komisaris bersifat independen, maka keputusan yang dihasilkan perusahaan akan bersifat netral. Penelitian terdahulu juga memberikan bukti bahwa dewan yang independen berpengaruh positif dengan tanggung jawab sosial perusahaan (Abu Qa'dan \& Suwaidan 2019), (Biswas et al., 2018), (Ibrahim \& Hanefah 2016), (Villegas et al., 2018), dan (Naseem et al., 2017). Sejalan dengan kajian empiris dapat dirumuskan hipotesis berikut ini:

$\mathrm{H}_{2}$ : Komisaris independen berpengaruh positif terhadap tanggung jawab sosial perusahaan.

Teori stakeholder menjelaskan jika dewan tidak hanya melindungi kepentingan pemegang sahamnya namun juga kepentingan semua pemangku kepentingan (Freeman, 1984). Ukuran dewan dapat berpengaruh cukup besar pada taraf mengungkap laporan tahunan, termasuk mengungkap pertanggung 
jawaban sosial perusahaan. Pengungkapan perusahaan ialah keputusan strategis supaya dipertimbangkan oleh dewan. Pemantauan, pengendalian, dan pelaporan perusahaan dipengaruhi dari ukuran dewan. Dewan yang semakin besar dapat menguntungkan perusahaan dalam beberapa cara, seperti memberikan peningkatan nilai perusahaan (Kalsie, 2016) atau kualitas pelaporan keuangan yang lebih tinggi (Obigbemi et al., 2016). Dengan demikian, salah satu atribut yang membuat dewan efektif dengan menekan tim manajemen untuk menyampaikan masalah tanggung jawab sosial perusahaan (Jizi et al., 2014). Bertambah besarnya ukuran dewan, membuat kemampuannya dalam melakukan kegiatan pertanggung jawaban sosial perusahaan juga bertambah besar (Abu Qa' dan \& Suwaidan 2019), (Martinez et al., 2019), dan (Naseem et al., 2017).

$\mathrm{H}_{3}$ : Ukuran dewan berpengaruh positif terhadap pengungkapan tanggung jawab sosial perusahaan.

Komite audit adalah anggota yang disusun oleh dewan komisaris yang tugasnya meringankan dewan komisaris dalam melaksanakan tugas fungsinya dalam mengawasi atas kegiatan perseroan. Komite audit sebaiknya memastikan integritas pelaporan keuangan dengan cara terus memantau dan memberikan kontrol (Fama \& Jensen, 1983). Akan tetapi, tujuannya tersebut tidak dapat dicapai tanpa komite audit efektif. Keefektifan komite audit tergantung pada sistem dan karakteristik perusahaan. Berdasar pada POJK 55/2015, komite audit setidaknya meliputi 3 (tiga) orang personil yakni satu orang sebagai ketua yang asalnya harus dari komisaris independen dan 2 anggota yang lain dari pihak eksternal, setidaknya mempunyai 1 (satu) anggota dengan latar belakang pendidikannya akuntansi dan keuangan. Keefektifan komite audit bisa dijadikan sebagai alat untuk memantau yang sukses dalam keputusan manajer, khususnya yang terkait dengan pertanggung jawaban sosial yang akan tergambar dalam pengungkapan tanggung jawab sosial perusahaan yang berkualitas tinggi (Habbash, 2016). Argumen ini relevan dengan teori agensi yang menjelaskan jika independensi dewan dan komite audit melemahkan asimetri informasi. Bertambah besarnya personel komite audit, pengawasan dan pemantauan terhadap prestasi kerja sosial akan makin meninggi (Fallah \& Mojarrad, 2019).

$\mathrm{H}_{4}$ : Komite audit berpengaruh positif terhadap pengungkapan tanggung jawab sosial perusahaan.

\section{METODE PENELITIAN}

Penelitian ini populasinya ialah semua perusahaan yang tercatat di database Global Reporting Index (GRI) tahun 2013-2018. Pengambilan sampelnya menggunakan teknik purposive sampling, secara rinci ditunjukkan dalam Tabel 1, Sampelnya berjumlah 340 perusahaan. Angka dari variabel penelitian berasal dari laporan tahunan serta laporan pertanggung jawaban sosial perusahaan apabila ditampilkan tersendiri. Pemilihan sampel penelitian disajikan dalam Tabel 1.

Tanggung jawab sosial perusahaan dinilai dengan Global Reporting Index (GRI). Setiap kategori informasi pengungkapan tanggung jawab sosial, skornya 1 apabila kategori keterangan disampaikan dalam laporan keberlanjutan atau laporan tahunan perusahaan, dan sebaliknya nilai 0 jika kategori informasi tidak 
diungkapkan (Garcia et al., 2018). Penelitiannya dimulai tahun 2013 sampai 2018. Mengikuti pedoman pelaporan dalam Global Reporting Index (GRI) terdapat tiga jenis Indeks Global Reporting Index (GRI) dalam periode tahun 2013-2018, yakni G3, G3.1, G4 dan GS.

Tabel 1. Pemilihan sampel penelitian

\begin{tabular}{|c|c|c|c|c|c|c|c|}
\hline No & Kriteria & 2013 & 2014 & 2015 & 2016 & 2017 & 2018 \\
\hline 1. & $\begin{array}{l}\text { Perusahaan terdaftar di database } \\
\text { Global Reporting Index (GRI) }\end{array}$ & 126 & 126 & 126 & 126 & 126 & 126 \\
\hline 2. & Perusahaa tidak terdaftar di BEI & (62) & (62) & (62) & (62) & (62) & (62) \\
\hline 3. & $\begin{array}{l}\text { Keterbatasan informasi dalam } \\
\text { laporan tahunan yang diterbitkan }\end{array}$ & (1) & (2) & (1) & (1) & (1) & (1) \\
\hline & $\begin{array}{l}\text { Data Outlier } \\
\quad \text { Total Sampel Terpilih }\end{array}$ & $\begin{array}{c}(18) \\
45\end{array}$ & $\begin{array}{l}(8) \\
54\end{array}$ & $\begin{array}{l}(3) \\
60\end{array}$ & $\begin{array}{l}(6) \\
57\end{array}$ & $\begin{array}{l}(2) \\
61\end{array}$ & $-\overline{63}$ \\
\hline
\end{tabular}

Sumber: Data Penelitian, 2020

Pengukuran pengungkapan tanggung jawab sosial menggunakan ketentuan berikut ini:

CSRDi $=\underset{n}{\sum X \mathrm{i}}$

Keterangan:

CSRDi = Pengungkapan tanggung jawab sosial perusahaan $\mathrm{i}$

$\sum X_{\mathrm{i}} \quad=$ Jumlah butir bernilai 1 pada perusahaan $\mathrm{i}$

$\mathrm{n} \quad$ = Banyaknya semua butir indikator pengungkapan tanggung jawab sosial perusahaan

Gender dinilai berdasarkan jumlah dewan direksi dan komisaris perempuan dibagi dengan keseluruhan anggota dewan direksi dan komisaris (Qa'dan \& Suwaidan, 2019) dan (Garcia et al., 2018)

Gender $=$ banyaknya dewan direksi dan komisaris perempuan

Keseluruhan anggota dewan direksi dan komisaris

Besaran dewan dinilai dengan banyaknya dewan direksi dan komisaris dalam perusahaan (Galbreath, 2016) dan (Cherian et al., 2019).

Ukuran dewan= jumlah dewan direksi + jumlah komisaris.

Komisaris independen diukur dengan banyaknya anggota komisaris independen dibagi dengan total keseluruhan anggota dewan komisaris.

Komisaris independen $=$ Banyaknya anggota komisaris independen.

Keseluruhan anggota dewan komisaris

Ukuran komite audit $=$ jumlah anggota komite audit.

Analisa regresi linear berganda dipakai untuk penentuan pengaruh variabel bebas dengan satu variabel terikat (Ghozali, 2013). Penelitian ini menggunakan program SPSS 22.0 untuk menguji hipotesis.

Model yang dipakai dalam pengujian hipotesisnya yaitu:

$Y=\alpha+\beta_{1} X_{1}+\beta_{2} X_{2}+\beta_{3} X_{3}+\beta_{4} X_{4}+\varepsilon$

Keterangan:

$\mathrm{Y} \quad=$ Pengungkapan tanggung jawab sosial perusahaan

$\mathrm{a} \quad=$ Konstanta

$\beta_{1}-\beta_{4} \quad=$ Koefisien regresi

$\mathrm{X}_{1} \quad=$ Gender

$\mathrm{X}_{2} \quad=$ Dewan komisaris independen 


$$
\begin{array}{ll}
\mathrm{X}_{3} & =\text { Ukuran dewan } \\
\mathrm{X}_{4} & =\text { Komite audit } \\
\varepsilon & =\text { Error }
\end{array}
$$

\section{HASIL DAN PEMBAHASAN}

Penelitian ini menguji data selama periode enam tahun (2013-2018) dengan total 340 perusahaan-tahun. Analisis deskriptif dipakai guna menggambarkan secara umum terkait dengan nilai minimal, maksimal, mean, dan standar deviasi masing-masing variabel yang dipakai. Uraian analisis penelitiannya bisa dicermati dalam Tabel 2.

Tabel 2. Hasil Uji Statistik Deskriptif

\begin{tabular}{lcccc}
\hline \multicolumn{1}{c}{ Variabel } & Min & Max & Mean & Std. Deviation \\
\hline Gender $(\mathrm{X} 1)$ & 0 & 0,5 & 0,1204 & 0,12248 \\
Komisaris Independen $(\mathrm{X} 2)$ & 0,2 & 0,83 & 0,4309 & 0,11993 \\
Ukuran Dewan $(\mathrm{X} 3)$ & 6 & 21 & 12,5088 & 3,18226 \\
Komite Audit $(\mathrm{X} 4)$ & 2 & 6 & 3,5588 & 0,86188 \\
CSRD $(\mathrm{Y})$ & 0,11 & 0,66 & 0,3552 & 0,11282 \\
\hline
\end{tabular}

Sumber: Data Penelitian, 2020

Mengacu dengan Tabel 2, variabel gender memiliki nilai antara 0-0,5, artinya masih sedikit perusahaan yang memiliki dewan direksi maupun komisaris perempuan terlihat dalam nilai mean sebesar 0,1204 yang lebih mendekati nilai minimum dibandingkan dengan nilai maksimumnya. Nilai standar deviasi sebesar 0,12248 lebih tinggi jika dibandingkan nilai mean menunjukkan bahwa data heterogen (bervariasi). Komisaris independen memiliki mean sebesar 0,4309, dengan nilai minimum sebesar 0,2 terdapat pada PT Indosat Tbk tahun 2014 dan nilai maksimum sebesar 0,83 terdapat pada PT Lippo Karawaci Tbk tahun 2016. Nilai mean sebesar 0,4309 lebih mendekati nilai minimum menunjukkan sedikitnya komisaris independen dalam perusahaan sampel. Standar deviasi komisaris independen sebesar 0,11993 memperlihatkan bahwa standar deviasi lebih kecil dari nilai mean, sehingga menunjukkan data homogen yang berarti bahwa variasi datanya rendah serta persebaran data tidak terlampau jauh dari nilai mean.

Ukuran dewan memiliki standar deviasi sebesar 3,18226, nilai ini lebih rendah dibanding dengan nilai mean menunjukkan bahwa sebaran data ukuran dewan merata atau rentang data satu dengan yang lainnya tidak tergolong tinggi. Rerata ukuran dewan direksi dan komisaris berada dikisaran 12 orang kendati perusahaan besar memiliki total dewan direksi dan komisaris hingga 21 orang. Rerata komite audit berada dikisaran 3 dan menunjukkan bahwa sebaran komite audit sudah merata diindikasikan dengan standar deviasi sebesar 0,86188 dan lebih rendah dari nilai mean, dengan jumlah tertinggi komite audit sebanyak 6 orang. Variabel terikat pengungkapan tanggung jawab sosial perusahaan memiliki mean 0,3552 yang mendekati nilai minimum memperlihatkan jika di Indonesia rata rata pengungkapan tanggung jawab sosial perusahaannya masih rendah. Variabel luas pengungkapan tanggung jawab sosial tidak terlalu bervariasi yaitu dengan standar deviasinya yang relatif kecil sebesar 0,11282, dengan nilai standar deviasi lebih rendah dari nilai mean menunjukkan bahwa sebaran data sudah merata dan tidak terlalu jauh dari nilai tengahnya. 
Uji normalitas dilakukan untuk menguji apakah residual model regresi berdistribusi normal atau tidak. Uji normalitas dalam penelitian ini dilakukan dengan menggunakan uji Kolmogorov smirnov, dengan kriteria data berdistribusi normal jika Asymp. Sig. (2-tailed) lebih besar dari a=0,05. Hasil uji normalitas berdasarkan Kolmogorov Smirnov ditampilkan pada Tabel 3.

Tabel 3. Hasil Uji Normalitas

\begin{tabular}{lc}
\hline \multicolumn{1}{c}{ Asymp. Sig. (2-tailed) } & Keterangan \\
\hline 0,091 & Sebaran data berdistribusi normal \\
\hline Sumber: Data Penelitian, 2020 &
\end{tabular}

Berdasarkan Tabel 3, hasil uji normalitas menunjukkan Asymp. Sig. (2tailed) sebesar 0,091, lebih besar dari tingkat signifikasi 0,05 dan dapat disimpulkan bahwa residual data dalam penelitian ini berdistribusi normal sehingga asumsi normalitas terpenuhi.

Uji multikolinearitas bertujuan menguji apakah pada model regresi ditemukan adanya korelasi antar variabel independen, yaitu antara variabel gender (X1), komisaris independen (X2), ukuran dewan (X3), dan komite audit (X4). Deteksi multikolineartas dilihat dari nilai tolerance dan nilai Variance Inflation Factor (VIF). Jika nilai tolerance $>0,10$ atau VIF $<10$, maka dapat dikatakan bebas dari multikolinearitas. Hasil uji multikolinearitas terdapat pada Tabel 4 .

Tabel 4. Hasil Uji Multikolinearitas

\begin{tabular}{lrrl}
\hline \multicolumn{1}{c}{ Variabel } & Tolerance & \multicolumn{1}{c}{ VIF } & Keterangan \\
\hline Gender $(\mathrm{X} 1)$ & 0,937 & 1,067 & Tidak terjadi Multikolinearitas \\
Komisaris Independen $(\mathrm{X} 2)$ & 0,890 & 1,124 & Tidak terjadi Multikolinearitas \\
Ukuran Dewan $(\mathrm{X} 3)$ & 0,901 & 1,110 & Tidak terjadi Multikolinearitas \\
Komite Audit $(\mathrm{X} 4)$ & 0,899 & 1,112 & Tidak terjadi Multikolinearitas \\
\hline
\end{tabular}

Sumber: Data Penelitian, 2020

Berdasarkan Tabel 4, hasil uji multikolinearitas menunjukkan bahwa nilai tolerance yang dimiliki oleh variabel gender (X1), komisaris independen (X2), ukuran dewan (X3), dan komite audit (X4) lebih besar dari 0,10 dan semua variabel independen memiliki nilai VIF kurang dari 10, maka dapat disimpulkan tidak terjadi multikolinearitas dalam model regresi.

Uji heteroskedastisitas bertujuan menguji apakah dalam model regresi terjadi ketidaksamaan variance dari residual satu pengamatan ke pengamatan lain. Pengujian heteroskedastisitas dilakukan dengan uji Glejser yaitu dengan meregresikan variabel independen dengan nilai absolut residual. Jika variabel independen yang diteliti tidak mempunyai pengaruh signifikan terhadap nilai absolut residual maka model regresi tidak mengandung gejala heteroskedastisitas. Model regresi yang baik adalah tidak terjadi heteroskedastisitas.

Tabel 5. Hasil Uji Heteroskedastisitas

\begin{tabular}{lcl}
\hline \multicolumn{1}{c}{ Variabel } & Sig. & Keterangan \\
\hline Gender $(\mathrm{X} 1)$ & 0,924 & Bebas Heteroskedastisitas \\
Komisaris Independen $(\mathrm{X} 2)$ & 0,073 & Bebas Heteroskedastisitas \\
Ukuran Dewan $(\mathrm{X} 3)$ & 0,847 & Bebas Heteroskedastisitas \\
Komite Audit $(\mathrm{X} 4)$ & 0,344 & Bebas Heteroskedastisitas \\
\hline
\end{tabular}

Sumber: Data Penelitian, 2020 
Berdasarkan Tabel 5, hasil uji heteroskedastisitas dengan uji Glejser menunjukkan bahwa nilai Sig. dari variabel independen yaitu gender (X1), komisaris independen (X2), ukuran dewan (X3), dan komite audit (X4) terhadap variabel absolut residual adalah lebih besar dari 0,05, sehingga dapat disimpulkan bahwa data yang digunakan dalam penelitian ini bebas dari gejala heteroskedastisitas.

Uji autokorelasi bertujuan menguji apakah dalam model regresi linier terdapat korelasi antara kesalahan pengganggu periode $t$ dengan kesalahan pengganggu pada periode sebelumnya $(\mathrm{t}-1)$. Model regresi yang baik adalah yang bebas dari autokorelasi.

Tabel 6. Hasil Uji Autokorelasi dengan Metode Cochrane-Orcutt

\begin{tabular}{cc}
\hline Durbin-Watson & Keterangan \\
\hline 1,977 & Bebas Autokorelasi \\
\hline
\end{tabular}

Sumber: Data Penelitian, 2020

Berdasarkan Tabel 6, hasil uji autokorelasi menunujukkan bahwa nilai Durbin Watson (DW Test) sebesar 1,977 dengan jumlah variabel independen sebanyak $4(\mathrm{k}=4)$ dan jumlah pengamatan sebanyak 340 , maka nilai $\mathrm{d}_{\mathrm{L}}=1,804 \mathrm{dan}$ $\mathrm{d}_{\mathrm{U}}=1,840$, sehingga $4-\mathrm{d}_{\mathrm{L}}=2,196$ dan $4-\mathrm{d}_{\mathrm{U}}=2,16$, maka dapat dirumuskan kriteria $\mathrm{d}_{\mathrm{U}}<\mathrm{DW}<4-\mathrm{d}_{\mathrm{U}}$ yaitu $1,840<1,977<2,16$. Keputusan yang dapat diambil adalah tidak terdapat autokorelasi.

Metode yang digunakan dalam menganalisis data adalah regresi linear berganda, yang tujuannya adalah membuktikan pengaruh variabel bebas terhadap variabel terikatnya. Hasil analisa regresi untuk menentukan persamaan regresi akan ditampilkan dalam tabel berikut.

Tabel 7. Hasil Analisis Regresi Linear Berganda

\begin{tabular}{lcccll}
\hline \multicolumn{1}{c}{ Variabel } & Koefisien & $\mathrm{t}$ & Sig. & Hasil Pengujian & Keterangan \\
\hline Constant & 0,284 & 8,447 & 0,000 & & \\
Gender (X1) & 0,029 & 0,589 & 0,556 & Tidak berpengaruh & H1 ditolak \\
Komisaris Ind. (X2) & $-0,180$ & $-3,435$ & 0,001 & Berpengaruh $(-)$ & H2 ditolak \\
Ukuran Dewan (X3) & 0,006 & 3,036 & 0,003 & Berpengaruh $(+)$ & H3 Diterima \\
Komite Audit (X4) & 0,020 & 2,750 & 0,006 & Berpengaruh $(+)$ & H4 Diterima \\
\hline
\end{tabular}

Sumber: Data Penelitian, 2020

Tabel 7, tersebut memperlihatkan angka koefisien regresi sehingga diperoleh model persamaan regresi berganda seperti sebagai berikut:

$$
\mathrm{Y}=0,284+0,029 \mathrm{X}_{1}-0,180 \mathrm{X}_{2}+0,006 \mathrm{X}_{3}+0,020 \mathrm{X}_{4}+\varepsilon
$$

Pengujian koefisien determinasi bertujuan guna mengidentifikasi sebesar apa pengaruh variabel gender, komisaris independen, ukuran dewan, dan komite audit yang digunakan dalam penelitian ini terhadap pengungkapan tanggung jawab sosial perusahaan. Hasil pengujian koefisien determinasinya bisa mencermati Tabel 8.

Tabel 8. Hasil Uji Koefisien Determinasi

\begin{tabular}{ccc}
\hline $\mathrm{R}$ & R Square & Adjusted R Square \\
\hline, $274^{\mathrm{a}}$ & 0,075 & 0,064 \\
\hline
\end{tabular}

Sumber: Data Penelitian, 2020

Tabel 8, memperlihatkan jika angka Adjusted RSquare adalah 0,064, dapat diartikan jika pengaruh variabel gender, komisaris independen, ukuran dewan 
dan komite audit terhadap tanggung jawab sosial perusahaan ialah sebesar $6,4 \%$, sedangkan sisanya dijelaskan oleh variabel lain diluar model regresi.

Berdasarkan Tabel 7, pengujian $t$ pada analisis regresi linier berganda menunjukkan hasil pengujian variabel gender $\left(\mathrm{X}_{1}\right)$ memiliki $p$-value 0,556 , $p$-value lebih besar dari a $(=0,05)$ maka dapat diambil keputusan $\mathrm{H}_{1}$ ditolak. Hasil tersebut memperlihatkan jika variabel gender tidak berpengaruh terhadap pengungkapan tanggung jawab sosial perusahaan, sejalan dengan penelitiann Qa' dan \& Suwaidan (2019) dan Majumder (2017). Hasil yang tidak signifikan ini tidak mendukung teori stakeholder. Konsisten dengan massa kritis yang menunjukkan jika tiga atau lebih perempuan bisa mengakibatkan perubahaan mendasar dalam keputusan rapat dewan (Cabeza Garcia et al., 2018). Ketika prosentase perempuan dalam suatu kelompok meningkat, mereka dapat membentuk koalisi dengan saling mendukung dan saling mempengaruhi. Mengingat bahwa perempuan di dewan direksi dan komisaris berada di posisi minoritas, kehadiran mereka mungkin tidak memungkinkan perubahan ini. Perempuan diyakini lebih baik daripada laki-laki dalam hal perilaku etis, diskriminasi terhadap perempuan dalam posisi kepemimpinan menghalangi mereka untuk menghasilkan pengungkapan tanggung jawab sosial yang lebih baik. Dalam keadaan ini, manfaat dari keragaman gender dewan dalam meningkatkan pengungkapan tanggung jawab sosial perusahaan tidak mungkin terealisasi.

Hasil uji hipotesis yang kedua menunjukkan hasil pengujian variabel komisaris independen $\left(X_{2}\right)$ dengan p-value 0,001 dan koefisien regresi yang memiliki tanda negatif, maka kesimpulan yang diambil dari hasil uji regresi linear berganda ini adalah komisaris independen berpengaruh negatif terhadap pengungkapan tanggung jawab sosial perusahaan. Hasil penelitian tidak mendukung teori keagenan. Independendesi dewan komisaris independen dinilai rendah karena keberadaan komisaris independen hanya demi memenuhi syarat dari Bapepam-LK dengan jumlah minimum 30\% komisaris independen dalam perusahaan dan sebagian perusahaan telah menerapkan adanya dewan komisaris independen sebagai formalitas untuk mematuhi peraturan, sehingga mengakibatkan kurangnya tingkat independensi dewan komisaris independen dalam mengawasi setiap pengungkapan tanggung jawab sosial perusahaan.

Contoh perusahaan yang memiliki proporsi dewan komisaris independen yang tinggi namun tingkat pengungkapan tanggung jawab sosial perusahaan rendah yaitu Lippo Karawaci Tbk, PT Bank OCBC NIPS Tbk, dan Bank Victoria International Tbk. Ketiga perusahaan ini memiliki proporsi dewan komisaris independen diatas 30\% namun pengungkapan tanggung jawab sosial perusahaan dibawah $50 \%$ dari seluruh indikator GRI. Alasan mengapa besarnya dewan komisaris independen tidak meningkatkan atau mendorong perusahaan melakukan pengungkapan tanggung jawab sosial perusahaan karena kemampuan komisaris independen dalam memantau proses keterbukaan akan terbatas apabila pihak-pihak yang terafiliasi dalam perusahaan lebih mendominasi dan dapat mngendalikan dewan komisaris secara keseluruhan. Hasil penelitian ini sejalan dengan penelitian Qa'dan \& Suwaidan (2019) yang menunjukkan bahwa independensi dewan mempunyai pengaruh negatif terhadap pengungkapan tanggung jawab sosial perusahaan, dan Naciti (2019) 
juga menunjukkan bahwa dewan yang independen berpengaruh negatif terhadap kinerja sosial, Seraphine (2014) juga menunjukkan bahwa dewan komisaris independen berpengaruh negatif terhadap pengungkapan tanggung jawab sosial perusahaan.

Pengujian hipotesis ketiga menggunakan uji-t yang didapatkan dari analisis regresi berganda dalam Tabel 7, menunjukkan bahwa ukuran dewan berpengaruh positif terhadap pengungkapan tanggung jawab sosial perusahaan. Hal ini ditunjukkan dari nilai koefisien regresi ukuran dewan yang memiliki tanda positif dan $p$-value yaitu $0,003<0,05$. Terdapat pengaruh positif ukuran dewan terhadap pengungkapan tanggung jawab sosial perusahaan sejalan dengan penelitian yang dilakukan oleh Villegas et al., (2018) dan Majumder et al., (2017). Hasil penelitiannya menguatkan teori stakeholder yang mengungkapkan manajer harus memperhitungkan kepentingan semua pemangku kepentingan perusahaan tidak cuma pemegang sahamnya (Freeman, 1984). Pemangku kepentingan disini merupakan orang-orang atau kelompok yang dapat mempengaruhi pencapaian tujuan perusahaan, dewan yang lebih besar dapat memberi perusahaan lebih banyak alternatif supaya bisa terkoneksi dengan pemangku kepentingan eksternal yang mengendalikan sumber daya yang dibutuhkan dalam mengoperasikan perusahaan (Chang, 2010). Koefisien positif pada ukuran dewan memperlihatkan jika dewan yang lebih tinggi bisa melakukan peningkatan dalam mengungkap pertanggung jawaban sosial perusahaan. Bertambahnya besarnya ukuran dewan, dewan akan semakin heterogen. Keragaman dewan dapat meningkatkan kreativitas dan inovasi bisnis, karena berbagai pendapat dan sudut pandang (Pucheta Martinez, 2019), sehingga hal ini dapat mempengaruhi dalam pembuatan keputusan dalam pengungkapan pertanggung jawaban sosial perusahaan.

Pengujian hipotesis keempat menununjukkan jika variabel komite audit memiliki $p$-value 0,006 dimana signifikan pada a $(0,05)$ artinya $p$-value $\leq a(0,05)$ dengan nilai koefisien regresi memiliki tanda positif, maka bisa ditentukan keputusan jika komite audit berpengaruh positif terhadap pengungkapan tanggung jawab sosial perusahaan. Adanya pengaruh antara variabel komite audit terhadap keputusan dalam mengungkapkan pertanggung jawaban sosial relevan dengan penelitian yang dilaksanakan Fallah \& Mojarrad (2019) dan Martinez (2019). Komite audit bisa meningkatkan kualitas dalam mengungkapkan pertanggung jawaban sosial perusahaan, sebab mereka dapat mendukung dan memberi bantuan pada manajemen perusahaan dalam menginformasikan sesuatu hal yang lebih berkualitas (Khan, 2019). Salah satu fungsi dari komite audit yaitu menyakinkan jika distem pengendalian intern perusahaan berjalan dengan baik (KNKG, 2006), dengan sistem pengendalian intern yang baik membuat organ-organ dalam perusahaan menjadi terintegrasi sehingga hal tersebut bisa menanggulangi persoalan terkait dengan agen. Ketika masalah keagenan dalam perusahaan dapat diminimalisir, maka informasi terkait dengan nilai-nilai sosial yang dibutuhkan oleh investor dapat diungkapkan secara penuh, sehingga hasil penelitiannya relevan dengan teori agensi. Perusahaan bisa melakukan peningkatan pengawasan terkait dengan aktivitas sosial perusahaan melalui peningkatan jumlah komite audit, makin bertambah banyak komite audit jadi bertambah baiknya dalam melakukan 
pengawasan menjadikan lancarnya aktivitas kegiatan sosial perusahaan dan legitimasi bisa terplihara dengan baik.

\section{SIMPULAN}

Berdasar pada hasil uji statistik dan pembahasannya, bisa disimpulkan jika ukuran dewan dan komite audit berhasil membuktikan adanya pengaruh positif terhadap pengungkapan tanggung jawab sosial perusahaan. Hasil penelitian tersebut membuktikan jika tata kelola perusahaan berperan dalam menentukan luasnya pengungkapan tanggung jawab sosial perusahaan. Penelitian ini tidak berhasil memberikan bukti terkait dengan pengaruh positif dewan komisaris independen terhadap pengungkapan tanggung jawab sosial perusahaan, dan tidak berhasil membuktikan pengaruh dewan direksi dan komisaris perempuan dalam meningkatkan pengungkapan tanggung jawab sosial perusahaan. Dalam sampel penelitian, rata-rata hanya terdapat $12 \%$ perempuan dalam anggota dewan direksi dan komisaris, sehingga mereka tergolong kelompok minoritas dalam anggota dewan. Meskipun Dienes dan Velte (2016) berpendapat bahwa perempuan cenderung mempengaruhi keputusan dalam pelaporan tanggung jawab sosial perusahaan karena perbedaan pengetahuan dan nilai-nilai mereka, namun suara mereka mungkin tidak terdengar karena jumlah mereka yang lebih kecil.

Penelitian ini mempunyai berbagai keterbatasan, yakni jumlah sampelnya hanya 340 perusahaan-tahun. Sehingga, saran bagi peneliti berikutnya ialah memperluas sampel dengan menambahkan jangka waktu penelitian, maka diharapkan hasil yang didapatkannya semakin akurat. Taraf Adjusted R2 yang rendah sebesar 6,4\% dalam penelitian ini, memperlihatkan jika terdapat variabel-variabel lain yang berpengaruh lebih besar terhadap pengungkapan tanggung jawab sosial perusahaan. Penulis menyarankan kepada peneliti berikutnya supaya menambah variabel bebasnya yang lain seperti menambahkan variabel strutur kepemilikan.

\section{REFERENSI}

Abu Qa'dan, Mohammad Bassam, and Mishiel Said Suwaidan. 2019. “Board Composition, Ownership Structure and Corporate Social Responsibility Disclosure: The Case of Jordan." Social Responsibility Journal 15(1):28-46.

Ahmad, Nurulyasmin Binti Ju, Afzalur Rashid, and Jeff Gow. 2018. “Corporate Board Gender Diversity and Corporate Social Responsibility Reporting in Malaysia." Gender, Technology and Development 22(2):87-108.

Azam, Muhammad, Muhammed Usman Khalid, and Syeda Zinnaira Zia. 2019. "Board Diversity and Corporate Social Responsibility: The Moderating Role of Shariah Compliance." Corporate Governance (Bingley) 19(6):1274-88.

Biswas, Pallab Kumar, Mansi Mansi, and Rakesh Pandey. 2018. "Board Composition, Sustainability Committee and Corporate Social and Environmental Performance in Australia." Pacific Accounting Review 30(4):517-40.

Cabeza Garcia, Laura, Roberto Fernandez Gago, and Mariano Nieto. 2018. “Do Board Gender Diversity and Director Typology Impact CSR Reporting?" European Management Review 15(4):559-75. 
Chang, William S. 2010. "Social Network and Corporate Financial Performance : Conceptual Framework of Board Composition and Corporate Social Responsibility." Journal of Business and Management 5(6):92-98.

Cherian, Jacob, Muhammad Umar, Phung Anh Thu, Thao Nguyen-Trang, Muhammad Safdar Sial, and Nguyen Vinh Khuong. 2019. “Does Cor porate Social Responsibility Affect the Financial Performance of the Manufacturing Sector? Evidence from an Emerging Economy." Sustainability (Switzerland) 11(4):1-14.

Clarkson, Max B. E. 1995. “A Stakeholder Framework for Analyzing and Evaluating Corporate Social Performance." The Academy of Management Review 20(1):92.

El-Bassiouny, Dina, and Noha El-Bassiouny. 2019. "Diversity, Corporate Governance and CSR Reporting: A Comparative Analysis between TopListed Firms in Egypt, Germany and the USA." Management of Environmental Quality: An International Journal 30(1):116-36.

Fallah, Mohammad Ali, and Fayegh Mojarrad. 2019. "Corporate Governance Effects on Corporate Social Responsibility Disclosure: Empirical Evidence from Heavy-Pollution Industries in Iran." Social Responsibility Journal 15(2):208-25.

Fama, Eugene F., and Michael C. Jensen. 1983. "Separation of Ownership and Control." Corporate Governance: Values, Ethics and Leadership XXVI(June):16388.

Fernández-Gago, Roberto, Laura Cabeza-García, and Mariano Nieto. 2016. "Corporate Social Responsibility, Board of Directors, and Firm Performance: An Analysis of Their Relationships." Review of Managerial Science 10(1):85104.

Freeman, R.Edward. 1984. "The Stakeholder Approach Revisited."

Galbreath, Jeremy. 2016. "Is Board Gender Diversity Linked to Financial Performance? The Mediating Mechanism of CSR." Business and Society 57(5):863-89.

Garcia-Sanchez, Isabel Maria, Beatriz Cuadrado-Ballesteros, and Cindy Sepulveda. 2014. "Does Media Pressure Moderate CSR Disclosures by External Directors?" Management Decision 52(6):1014-45.

El Ghoul, Sadok, Omrane Guedhami, Chuck C. Y. Kwok, and Dev R. Mishra. 2011. "Does Corporate Social Responsibility Affect the Cost of Capital?" Journal of Banking and Finance 35(9):2388-2406.

Guerrero Villegas, Jaime, Leticia Perez Calero, Jose Manuel Hurtado Gonzalez, and Pilar Giraldez Puig. 2018. "Board Attributes and Corporate Social Responsibility Disclosure: A Meta-Analysis." Sustainability (Switzerland) 10(12):1-22.

Habbash, Murya. 2016. "Corporate Governance and Corporate Social Responsibility Disclosure: Evidence from Saudi Arabia." Social Responsibility Journal 12(4):740-54.

Ibrahim, Abdul Hadi, and Mustafa Mohd Hanefah. 2016. "Board Diversity and Corporate Social Responsibility in Jordan." Journal of Financial Reporting and Accounting 14(2):279-98.

Imam Ghozali. 2013. Aplikasi Analisis Multivariate Dengan Program IBM SPSS 21 
Update PLS Regresi.

Jizi, Salama, Dixon, Stratling, Rebecca. 2014. “Corporate Governance and Corporate Social Responsibility Disclosure : Evidence from the US Banking Sector." Journal of Business Ethics 601-15.

John Elkington. 1997. "Enter the Triple Bottom Line."

Kabir, Rezaul, and Hanh Minh Thai. 2017. "Does Corporate Governance Shape the Relationship between Corporate Social Responsibility and Financial Performance?" Pacific Accounting Review 29(2):227-58.

Kalsie, Anjala. 2016. "Analysis of Board Size and Firm Performance : Evidence from NSE Companies Using Panel Data Approach." Indian Journal of Corporate Governance.

Katmon, Nooraisah, Zam Zuriyati Mohamad, Norlia Mat Norwani, and Omar Al Farooque. 2017. "Comprehensive Board Diversity and Quality of Corporate Social Responsibility Disclosure: Evidence from an Emerging Market." Journal of Business Ethics 157(2):447-81.

Khan, Imran, Ismail Khan, and Ismail Senturk. 2019. "Board Diversity and Quality of CSR Disclosure: Evidence from Pakistan." Corporate Governance (Bingley) 19(6):1187-1203.

KNKG. 2006. Pedoman Umum Good Corporate Governance.

Lawrence Loh, et al., 2016. "Pelaporan Yang Berkelanjutan Di ASEAN."

Liao, Lin, Le Luo, and Qingliang Tang. 2015. "Gender Diversity, Board Independence, Environmental Committee and Greenhouse Gas Disclosure." British Accounting Review 47(4):409-24.

Majumder, Md Tofael Hossain, Aklima Akter, and Xiaojing Li. 2017. "Corporate Governance and Corporate Social Disclosures: A Meta-Analytical Review." International Journal of Accounting and Information Management 25(4):434-58.

Martínez-Ferrero, Jennifer, Isabel M. Garcia-Sanchez, and Beatriz CuadradoBallesteros. 2015. "Effect of Financial Reporting Quality on Sustainability Information Disclosure." Corporate Social Responsibility and Environmental Management 22(1):45-64.

Michelon, Giovanna, Silvia Pilonato, and Federica Ricceri. 2015. “CSR Reporting Practices and the Quality of Disclosure: An Empirical Analysis." Critical Perspectives on Accounting 33:59-78.

Muttakin, Mohammad Badrul, Arifur Khan, and Nava Subramaniam. 2015. "Firm Characteristics, Board Diversity and Corporate Social Responsibility: Evidence from Bangladesh." Pacific Accounting Review 27(3):353-72.

Naciti, Valeria. 2019. "Corporate Governance and Board of Directors: The Effect of a Board Composition on Firm Sustainability Performance." Journal of Cleaner Production 237:117727.

Naseem, Muhammad Akram, Salman Riaz, Ramiz Ur Rehman, Amir Ikram, and Fizzah Malik. 2017. "Impact of Board Characteristics on Corporate Social Responsibility Disclosure." Journal of Applied Business Research 33(4):799-808.

Noviani, Komang, Gede Adi Yuniarta, and Made Arie Wahyuni. 2017. "Pengaruh Tingkat Profitabilitas, Komposisi Dewan Komisaris Independen, Dan Kepemilikan Institusional Terhadap Pengungkapan Corporate Social Responsibility Perusahaan Perbankan Yang Terdaftar Di Bursa Efek Indonesia Tahun 2014 - 2016." E-Journal Akuntansi 8(2). 
Obigbemi, Imoleayo F., Eddy O. Omolehinwa, Dick Oluku Mukoro, Egbide Bencaleb, and Olamide Adeola Olusanmi. 2016. "Earnings Management and Board Structure : Evidence From Nigeria."

Pucheta Martinez, Maria Consuelo, and Isabel Gallego Alvarez. 2019. “An International Approach of the Relationship between Board Attributes and the Disclosure of Corporate Social Responsibility Issues." Corporate Social Responsibility and Environmental Management 26(3):612-27.

Rao, Kathyayini, and Carol Tilt. 2016. "Board Diversity and CSR Reporting: An Australian Study." Meditari Accountancy Research 24(2):182-210.

Samaha, Khaled, Khaled Dahawy, Ahmed Abdel-Meguid, and Sara Abdallah. 2012. "Propensity and Comprehensiveness of Corporate Internet Reporting in Egypt: Do Board Composition and Ownership Structure Matter?" International Journal of Accounting and Information Management 20(2):142-70.

Seraphine Nathania, Purwatiningsih. 2014. "Analisis Pengaruh Struktur Kepemilikan Dan Independensi Dewan Komisaris Terhadap Tingkat Pengungkapan Tanggung Jawab Sosial." (1995).

Siregar, Reza Manjalang Muda, and Denies Priantinah. 2017. "Pengaruh Good Corporate Governance Dan Kepemilikan Saham Publik Terhadap Tingkat Pengungkapan Corporate Social Responsibility." Jurnal Profita 6(40):1-18.

Yuliani. 2019. "Pengaruh Mekanisme Good Corporate Governance Pada Pengungkapan Tanggung Jawab Sosial Perusahaan Yang Tergabung Dalam Indeks Kompas 100." JWM (Jurnal Wawasan Manajemen) 6(3):209.

Zhuang, Yiming, Xinyue Chang, and Younggeun Lee. 2018. "Board Composition and Corporate Social Responsibility Performance: Evidence from Chinese Public Firms." Sustainability (Switzerland) 10(8). 